\title{
Double Jeopardy and Dual Sovereignty Doctrine: Gamble v. United States ${ }^{1}$
}

Ne bis in idem y Doctrina de la Soberanía Dual: Gamble v. United States

\author{
Javier Escobar Veas ${ }^{1}$ \\ ${ }^{1}$ Universidad Mayor, Chile \\ Orcid: https://orcid.org/0000-0001-9266-0396
}

Para citación: Javier Escobar Veas, Double Jeopardy and dual Sovereignty Doctrine: Gamble v. United States, DOI: https://doi.org/10.22235/rd.vi20.1842 , Revista de Derecho N. 20 (2-2019): 225-244. ISSN 1510-3714, ISSN on line 2393-6193.

\begin{abstract}
:
In Gamble v. United States, the defendant questioned the constitutionality of the dual sovereignty doctrine under the double jeopardy clause. In its judgment, delivered on 17 June 2019, the United States Supreme Court upheld the application of the dual sovereignty doctrine, according to which different sovereigns may prosecute an individual without violating the double jeopardy clause if the individual's act infringed the laws of each sovereignty. This comment aims to address the reasoning of the Supreme Court and the rationale of the dual sovereignty doctrine, suggesting the convenience and necessity of a further study on its limits and possible safeguards against potential abuses.
\end{abstract}

KEYWORDS: Double jeopardy, multiple prosecutions, dual sovereignty doctrine.

\section{RESUMEN:}

En Gamble v. United States, el imputado cuestionó la constitucionalidad de la doctrina de la soberanía dual, en el contexto de la garantía non bis in ídem. En su sentencia, de 17 de junio de 2019, la Corte Suprema de los Estados Unidos confirmó la aplicación de

1 Recibido: 13/08/19. Evaluado: 23/08. Observado y corregido: 30/09. Aceptado: $3 / 10 / 19$.

N. E.: El comentario fue escrito en inglés, idioma de la sentencia, debido a las dificultades para traducir con fidelidad algunos términos clave en aquella. 
la doctrina de la soberanía dual, conforme a la cual distintas soberanías pueden enjuiciar a una persona, sin violar el ne bis in idem, si la conducta del imputado infringió las leyes de cada una de ellas. El presente comentario tiene por objeto abordar el razonamiento de la Corte Suprema y el fundamento de la doctrina de la soberanía dual, abogando por la conveniencia y necesidad de un estudio profundizado sobre sus límites y posibles salvaguardias en contra de posibles abusos.

Palabras Clave: ne bis in idem, persecuciones múltiples, doctrina de la soberanía dual.

Summary: Introduction. The case. Reasoning of the Supreme Court. Comment. 1. Definition of sovereign for double jeopardy purposes. 2. Is there any safeguard against the dual sovereignty doctrine? Bibliography.

\section{Introduction}

On 17 June 2019, the United States Supreme Court delivered a 7-2 decision in Gamble v. United States, ${ }^{2}$ upholding its long-standing dual sovereignty doctrine under the double jeopardy clause of the Fifth Amendment to the United States Constitution.

In Gamble v. United States, the defendant was convicted of possessing a firearm, contrary to Alabama legislation. After the accused pleaded guilty to this state offence, federal prosecutors charged him with the federal version of the same offence, based on the same instance of possession. Gamble filled a motion to dismiss, arguing that the following federal prosecution was for "the same offence" and thus exposed him to double jeopardy. The District Court denied Gamble's motion to dismiss, decision affirmed by the Eleventh Circuit.

In Gamble, the Supreme Court had to address once again the question whether the double jeopardy clause, which prohibits any person from being punished or prosecuted for the same offence more than once, bars a federal prosecution after a state prosecution for the same offence.

\footnotetext{
2 Gamble v. United States, 587 U.S. (2019), available in: https://www.supremecourt.gov/opinions/18pdf/17-646_d18e.pdf.
} 
In its decision, the Supreme Court upheld the dual sovereignty doctrine, concluding that the federal government and a state government can bring separate criminal prosecutions against the same person for the same conduct. Because each sovereign can define its own offences, the Court explained that a single act can qualify as two separate "offences", since a person can violate different sovereigns' laws at the same time.

Notwithstanding Gamble v. United States was a 7-2 decision, the concurring and dissenting opinions could presage eventual discussions about stare decisis. For example, although Justice Thomas joined the majority, he wrote a concurring opinion calling on the Court to reconsider precedent that it deems inconsistent with the "original understanding" of the relevant constitutional or statutory text. Justice Gorsuch, for his part, criticised the Court's stare decisis approach, but dissented because he would have rejected the dual sovereignty doctrine even under the existing stare decisis framework. Justice Ginsburg wrote a separate dissent that also noted how the rationale for stare decisis is weakest in cases concerning how procedural rules implicate fundamental constitutional protections.

This comment aims to address the rationale and basis of the dual sovereignty doctrine, which has been developed and endorsed by the Supreme Court in a case law of 150 years, and recently upheld in Gamble v. United States. Considering the decision in Gamble, it is highly probable that the Supreme Court will not overrule its case law on this matter. Therefore, a further study on its limits and possible safeguards is recommended.

\section{The case}

In 2008, Terance Martez Gamble was convicted of second-degree robbery in Alabama. In November 2015, a local police officer in Mobile, Alabama, pulled Gamble over for a damaged headlight. Smelling marijuana, the officer searched Gamble's car, where he found a firearm. Since Gamble had been convicted of second-degree robbery, his possession of the handgun violated an Alabama law providing that no one convicted of 
"a crime of violence" "shall own a firearm or have one in his or her possession". 3 Gamble pleaded guilty and was sentenced to one year in prison.

After Gamble's conviction, federal prosecutors charged him with the federal version of the same offence -one forbidding those convicted of "a crime punishable by imprisonment for a term exceeding one year (...) to ship or transport in interstate or foreign commerce, or possess in or affecting commerce, any firearm or ammunition"-, based on the same instance of possession. ${ }^{4}$

Gamble filled a motion to dismiss, arguing that the federal indictment was for "the same offence" and thus the federal prosecution was barred by the double jeopardy clause. Relying on the dual sovereignty doctrine, the District Court denied defendant's motion to dismiss. Gamble then pleaded guilty to the federal offence while preserving his right to challenge the denial of his motion to dismiss on double jeopardy grounds. ${ }^{5}$

Gamble appealed the district court's denial of his motion to the Eleventh Circuit Court of Appeals, which affirmed the decision based on the dual sovereignty doctrine. ${ }^{6}$

The defendant then filed a petition for a writ of certiorari with the Supreme Court, which was granted in order to consider "whether the Court should overrule the 'separate sovereigns' exception to the Double Jeopardy Clause". 7

\section{Reasoning of the Supreme Court}

1. Justice Alito, writing for the majority, first clarified that, although the dual sovereignty rule is often dubbed an "exception" to the double jeopardy clause, it is not an exception at all. On the contrary, it flows from the explicit textual reference to an "offence". 8

\footnotetext{
${ }^{3}$ Gamble v. United States, 587 U.S. 2 (2019).

${ }^{4}$ Gamble v. United States, 2.

${ }^{5}$ Gamble v. United States, 2.

6 Kayla Mullen. "Gamble v. United States: A Commentary". Duke Journal of Constitutional Law \& Public Policy, v. 14, n. 1 (2019): pp. 209.

${ }^{7}$ Gamble v. United States, Question Presented, Certiorari Granted on 28 June, 2018.

${ }^{8}$ Gamble v. United States, 3.
} 
2. The Court focused on the meaning of the word "offence", which was originally understood as the transgression or violation of a law. ${ }^{9}$ Offences are defined by a law, and each law is defined by a sovereign. ${ }^{10}$ In this regard, the Court cited Moore v. The People of the State of Illinois, which underlined that "the constitutional provision is not that no person shall be subject, for the same act, to be twice put in jeopardy of life or limb; but for the same offence, the same violation of law, no person's life or limb shall be twice put in jeopardy". ${ }^{11}$ The Court affirmed that there is no reason to abandon this sovereign-specific reading of the phrase "same offence", from which the dual sovereignty rule follows. ${ }^{12}$ Thus, even if federal and state prosecutions are based on the same conduct, the offences are not the same, because one offence violates state law and the other offence violates Federal law.

3. The Court emphasised that its reading of the double jeopardy clause is consistent with its case law and respects the possibility that two sovereigns could have different interests "in punishing the same act". The question of successive federal and state prosecutions was addressed by the Court in three antebellum cases. ${ }^{13}$ In Fox v. Ohio, the Supreme Court affirmed that the nature of the crime or its effects on public safety might well demand separate prosecutions. ${ }^{14}$ In United States v. Marigold, the Court generalised the previous idea and declared that "the same act might, as to its character and tendencies, and the consequences it involved, constitute an offence against both the State and Federal governments, and might draw to its commission the penalties denounced by either, as appropriate to its character in reference to each". ${ }^{15}$ The third antebellum case was Moore v. Illinois. In this case, the Court highlighted that the Fifth Amendment prohibits double jeopardy not "for the same act" but "for the same

\footnotetext{
${ }^{9}$ Huntington v. Attrill, 146 U.S. 657, 667 (1892); Kokesh v. Securities and Exchange Commission, 581 U.S., 5 (2017).

${ }^{10}$ Gamble v. United States, 3-4.

${ }^{11}$ Gamble v. United States, 4; Moore v. The People of the State of Illinois, 55 U.S. (14 How.) 13, 17 (1852).

${ }^{12}$ Gamble v. United States, 5.

${ }^{13}$ Gamble v. United States, 6-7.

${ }^{14}$ Fox v. The State of Ohio, 46 U.S. 410, 435 (1847).

${ }^{15}$ United States v. Marigold, 50 U.S. 560, 569 (1850).
} 
offence". ${ }^{16}$ Since "an offence, in its legal signification, means the transgression of a law", ${ }^{17}$ the Court concluded that a single act may be an offence or transgression of the laws of two sovereigns, and hence punishable by both. ${ }^{18}$ The underlying idea to these three cases was straightforward: a crime against two sovereigns constitutes two offences.

The Supreme Court cemented this idea 70 years after, in United States v. Lanza. The Court upheld a federal prosecution that followed a state prosecution, ruling that "an act denounced as a crime by both national and state sovereignties is an offence against the peace and dignity of both and may be punished by each". ${ }^{19}$ The precedent in Lanza was subsequently applied in several cases, such as Screws v. United States, ${ }^{20}$ Jerome v. United States, ${ }^{21}$ Westfall v. United States, ${ }^{22}$ and Hebert v. Louisiana, among others. ${ }^{23}$ In 1959, the Supreme Court reaffirmed once again its doctrine, in Bartkus v. Illinois and Abbate v. United States, finding no consideration or persuasive reason to overruled Lanza. ${ }^{24}$ After these two cases, the Court has applied the dual sovereignty doctrine during six decades of cases. ${ }^{25}$

4. The Supreme Court utilised, among others, probably the more provocative example of a prosecution in the United States for a crime committed abroad. In this regard, the Court pointed out that if, as the defendant argued, "only one sovereign may prosecute for a single act, no American court -state or federal- could prosecute conduct already tried in a foreign court" ${ }^{26}$ For example, if a U. S. national is murdered abroad, the other

\footnotetext{
${ }^{16}$ Moore v. The People of the State of Illinois, 55 U.S. (14 How.) 13, 17 (1852).

${ }^{17}$ Moore v. The People of the State of Illinois, 19.

${ }^{18}$ Moore v. The People of the State of Illinois, 20.

${ }^{19}$ United States v. Lanza, 260 U.S. 377, 382 (1922).

${ }^{20}$ Screws v. United States, 325 U.S. 91, 108 (note 10) (1945).

${ }^{21}$ Jerome v. United States, 318 U.S. 101, 105 (1943).

${ }^{22}$ Westfall v. United States, 274 U.S. 256, 258 (1927).

${ }^{23}$ Hebert v. Louisiana, 272 U.S. 31, 314 (1926).

${ }^{24}$ Abbate v. United States, 359 U. S. 187, 195 (1959). Similarly, Bartkus v. Illinois, 359 U.S. 121 (1959).

${ }^{25}$ See Heath v. Alabama, 474 U. S. 82 (1985), United States v. Wheeler, 435 U. S. 313 (1978), and Rinaldi v. United States, 434 U. S. 22 (1977), among others.

${ }^{26}$ Gamble v. United States, 7.
} 
country will rightfully seek to punish the killer. The foreign country's interest lies in protecting the peace in its territory rather than protecting the American specifically. However, the United States looks at the same conduct and sees an act of violence against one of its nationals. The murder of a U. S. national is an offence to the United States as much as it is to the country where the murder occurred and to which the victim is a stranger. That is why, explained the Court, the killing of an American abroad is a federal offence that can be prosecuted in the American courts. ${ }^{27}$

5. The Court addressed the counter argument that it is an error treating the federal and state governments as two separate sovereigns because sovereignty belongs to the people. The concept of sovereignty would be unitary, not dual. The Court replied that that argument is based on a non sequitur. ${ }^{28}$ It is true that the Constitution rests on the principle that the people are sovereign, but that does not mean that the people conferred all the attributes of sovereignty on a single government. Instead, the people, by adopting the Constitution, "split the atom of sovereignty". ${ }^{29}$

6. Gamble also argued that the recognition of the double jeopardy Clause's incorporation against the states in Benton v. Maryland ${ }^{30}$ washed away any theoretical foundation for the dual sovereignty doctrine. ${ }^{31}$ The Supreme Court rejected his argument, stating that the premises of the dual sovereignty doctrine have survived incorporation intact. "Incorporation meant that the States were now required to abide by this Court's interpretation of the Double Jeopardy Clause. But that interpretation has long included the dual sovereignty doctrine, and there is no logical reason why incorporation should change it". 32

After all, the dual sovereignty doctrine rests on the fact that only same sovereign successive prosecutions are prosecutions for the "same offence", and that is just as true after incorporation as before. ${ }^{33}$

\footnotetext{
${ }^{27}$ Gamble v. United States, 7.

${ }^{28}$ Gamble v. United States, 8-9.

${ }^{29}$ Gamble v. United States, 9.

${ }^{30}$ Benton v. Maryland 395 U. S. 784, 794 (1969).

${ }^{31}$ Gamble v. United States, 29.

${ }^{32}$ Gamble v. United States, 30.

${ }^{33}$ Gamble v. United States, 30.
} 


\section{Comment}

The Fifth Amendment provision against double jeopardy is one of the basic protections afforded defendants by the United States Constitution. ${ }^{34}$ The Fifth Amendment reads in part: "Nor shall any person be subject for the same offense to be twice put in jeopardy of life or limb".

The United States Constitution was the first major constitutional instrument in recognising the protection against double jeopardy, and was largely inspired by the operation in English law of what are referred to as pleas in bar. ${ }^{35}$ Even though the precise origins of the protection are unclear, ${ }^{36}$ there is no doubt that the double jeopardy possesses a long history. ${ }^{37}$ As Justice Black correctly affirmed, the protection against

34 Jay Sigler. "Federal Double Jeopardy Policy", Vanderbilt Law Review, v. 19, n 2 (1966): 375 .

35 Andrea Koklys. "Second Chance for Justice: Reevaluation of the United States Double Jeopardy Standard", John Marshall Law Review, v. 40, n. 1 (2006): 379; Brian Summers. "Double Jeopardy: Rethinking the Parameters of the Multiplicity Prohibition", Ohio State Law Journal, v. 56, n. 5 (1995): 1595.

${ }^{36}$ For example, David Rudstein and Jay Sigler state that the Code of Hammurabi made no reference to double jeopardy clause. Jay Sigler. "A History of Double Jeopardy", American Journal of Legal History, v. 7, n. 4 (1963): 284 (note 6); David Rudstein. “A Brief History of the Fifth Amendment Guarantee Against Double Jeopardy", William \& Mary Bill of Rights Journal, v. 14, n. 1 (2005): 196. Instead, Thomas III affirms that "laws against changing a final judgment can be traced to the Code of Hammurabi". George Thomas III. Double Jeopardy. The History, the Law (New York: New York University Press, 1998), 1. Similarly, Darius Patraus. "The non bis in idem principle in the case law of the Court of Justice of the European Union -consistency or inconsistency?”, AGORA International Journal of Juridical Sciences, n. 1 (2018): 26.

37 Rudstein. "A Brief History of the Fifth Amendment Guarantee Against Double Jeopardy", 196. 
being tried twice for the same offence is one of the oldest ideas found in western civilization, which roots run deep into Greek and Roman times. ${ }^{38}$

According to the Supreme Court case law, the double jeopardy clause provides three basic related protections: "It protects against a second prosecution for the same offense after acquittal. It protects against a second prosecution for the same offense after conviction. And it protects against multiple punishments for the same offense". 39

Nevertheless, under the dual sovereignty doctrine ${ }^{40}$ different sovereigns may prosecute an individual without violating the double jeopardy clause if the individual's act infringed the laws of each sovereignty. ${ }^{41}$

As the Supreme Court underlined in Gamble v. United States, the essence of the dual sovereignty doctrine is the common law conception of crime as an offence against the sovereignty of the government. ${ }^{42}$ When a defendant in a single act violates the "peace and dignity" of two sovereigns by breaking the laws of each, he committees two distinct offences. $^{43}$

${ }^{38}$ Bartkus v. Illinois, 359 U.S. 121, 151-152 (1959) (Black, J., dissenting).

${ }^{39}$ North Carolina v. Pearce, 395 U.S. 711, 717 (1969); United States v. Wilson, 420 U.S. 332, 343 (1975); Rudstein. "A Brief History of the Fifth Amendment Guarantee Against Double Jeopardy", 193-194; Adam Adler. "Dual Sovereignty, Due Process, and Duplicative Punishment: A New Solution to an Old Problem", Yale Law Journal, v. 124, n. 2 (2014): 450.

${ }^{40}$ For a general explanation, see David Rudstein. Double Jeopardy. A Reference Guide to the United States Constitution (Westport: Praeger, 2004), 84-92.

41 Adler. "Dual Sovereignty, Due Process, and Duplicative Punishment: A New Solution to an Old Problem", 450.

${ }^{42}$ Heath v. Alabama, 88; Akhil Reed and Jonathan Marcus. "Double Jeopardy Law After Rodney King”, Columbia Law Review, v. 95, n. 1 (1995): 5; James King. "The Problem of Double Jeopardy in Successive Federal-State Prosecutions: A Fifth Amendment Solution", Stanford Law Review, v. 31, n. 3 (1979): 484; Jay Brickman. "The Dual Sovereignty Doctrine and Successive State Prosecutions: Health v. Alabama", Chicago-Kent Law Review, v. 63, n. 1 (1987): 176.

${ }^{43}$ United States v. Lanza, 382; Ray Stoner. "Double Jeopardy and Dual Sovereignty: A Critical Analysis", William \& Mary Law Review, v. 11, n. 4 (1970): 946; Adler. "Dual 
The dual sovereignty doctrine was firstly recognized to protect principles of federalism. ${ }^{44}$ As correctly indicated, "behind the dual sovereign debate is a conflict between two ancient legal principles: sovereignty and double jeopardy". ${ }^{45}$ The Supreme Court was concerned that an expansive reading of the double jeopardy clause would bar either the federal government or individual state governments from enforcing their respective criminal laws. ${ }^{46}$ Binding the federal or state prosecution to the first adjudication would result in a "race of offenders". Defendants will plead guilty in the jurisdiction with the lesser fines or punishments, securing immunity from the harsher law. ${ }^{47}$ As previously said, in Moore v. Illinois the Supreme Court affirmed that "every citizen of the United States is also a citizen of a state or territory. He may be said to owe allegiance to two sovereigns and may be liable to punishment for an infraction of the laws of either. The same act may be an offence or transgression of the laws of both".

Sovereignty, Due Process, and Duplicative Punishment: A New Solution to an Old Problem", 450.

${ }^{44}$ Erin Cranman. "The Dual Sovereignty Exception to Double Jeopardy: A Champion of Justice or a Violation of a Fundamental Right", Emory International Law Review, v. 14, n. 3 (2000): 1654; Walter Fisher. "Double Jeopardy, Two Sovereignties and the Intruding Constitution”, The University of Chicago Law Review, v. 28, n. 4 (1961): 599. 45 David Owsley. "Accepting the Dual Sovereignty Exception to Double Jeopardy: A Hard Case Study”, Washington University Law Review, v. 81, n. 3 (2003): 797.

${ }^{46}$ Daniel Principato. "Defining the Sovereign in Dual Sovereignty: Does the Protection against Double Jeopardy Bar Successive Prosecutions in National and International Courts", Cornell International Law Journal, v. 47, n. 3 (2014): 773; Cranman. "The Dual Sovereignty Exception to Double Jeopardy: A Champion of Justice or a Violation of a Fundamental Right", 1654. King has pointed out that "this rule is based on an abstract theory -that of "dual sovereignty"- and a practical concern -that a contrary rule would allow one government to effectively nullify the other government's law". King. "The Problem of Double Jeopardy in Successive Federal-State Prosecutions: A Fifth Amendment Solution", 477.

${ }^{47}$ United States v. Lanza, 385. A similar argument can be found in Heath v. Alabama, 93. 
Therefore, "that either or both may (if they see fit) punish such an offender, cannot be doubted". 48

In Heath v. Alabama, ${ }^{49}$ the Supreme Court addressed the question whether the dual sovereignty doctrine permitted successive prosecutions under the laws of different states which otherwise would be held to subject the defendant for the same offence to be twice put in jeopardy. ${ }^{50}$ The Court concluded that the dual sovereignty doctrine, as originally articulated and consistently applied, compels the conclusion that successive prosecutions by two states for the same conduct are not barred by the double jeopardy clause, ${ }^{51}$ because "the states are no less sovereign with respect to each other than they are with respect to the Federal Government". ${ }^{52}$ The interest of a state in vindicating its sovereign authority through enforcement of its laws by definition can never be satisfied by the enforcement of another state of its own laws. ${ }^{53}$

The Supreme Court exemplified the foregoing reasoning with the case of a prosecution in the United States for a crime committed abroad. Since two sovereigns can have different interests in punishing the same conduct, it would be a mistake to prohibit one of them from prosecuting the defendant just because the other did it first, especially if it is considered that none of them can prevent the prosecution of the other one. International law instruments have adopted the same approach. Indeed, at international level the protection against double jeopardy is limited to multiple prosecutions or punishments within a single state ${ }^{54}$ accepting therefore subsequent prosecutions in

${ }^{48}$ Moore v. The People of the State of Illinois, 20.

49 For a positive comment, see Brickman. "The Dual Sovereignty Doctrine and Successive State Prosecutions: Health v. Alabama”, 183-188.

${ }^{50}$ Heath v. Alabama, 88

51 Heath v. Alabama, 88; Cranman. "The Dual Sovereignty Exception to Double Jeopardy: A Champion of Justice or a Violation of a Fundamental Right”, 1655.

${ }^{52}$ Heath v. Alabama, 89.

${ }^{53}$ Heath v. Alabama, 93. For a critical comment on the Court's arguments in Heath v. Alabama, see Ronald Allen and John Ratnaswamy. "Heath v. Alabama: A Case Study of Doctrine and Rationality in the Supreme Court", Journal of Criminal Law and Criminology, v. 76, n. 4 (1985): 814-824.

54 Anthony Colangelo. "Double Jeopardy and Multiple Sovereigns: A Jurisdictional Theory”, Washington University Law Review, v. 86, n. 4 (2009): 779. 
different states. This lack of an international protection against double jeopardy has been explained affirming that under a jurisdictional theory "each state as an independent lawgiver may exercise its national jurisdiction to apply and enforce its own laws". 55 In conclusion, the dual sovereignty doctrine denies double jeopardy protection in three circumstances: (1) successive prosecutions of an individual by multiple state governments; (2) successive prosecutions of an individual by a state and the federal government; and (3) successive prosecutions of an individual by a state or the federal government and a foreign government. ${ }^{56}$ By contrast, successive prosecutions for the same offence by the same sovereign are prohibited by the protection against double jeopardy. ${ }^{57}$ The dual sovereignty doctrine can be understood therefore to allow both horizontal prosecutions between states and vertical prosecutions between a state and the federal government. ${ }^{58}$

\section{Definition of sovereign for double jeopardy purposes}

Since the protection against double jeopardy only bars successive prosecutions by the same sovereign, it is crucial to define the term "sovereign". ${ }^{59}$ The Supreme Court has

55 Colangelo. "Double Jeopardy and Multiple Sovereigns: A Jurisdictional Theory", 779 .

56 Cranman. "The Dual Sovereignty Exception to Double Jeopardy: A Champion of Justice or a Violation of a Fundamental Right", 1644; Principato. "Defining the Sovereign in Dual Sovereignty: Does the Protection against Double Jeopardy Bar Successive Prosecutions in National and International Courts", 773.

${ }^{57}$ Principato. "Defining the Sovereign in Dual Sovereignty: Does the Protection against Double Jeopardy Bar Successive Prosecutions in National and International Courts", 774.

${ }^{58}$ Principato. "Defining the Sovereign in Dual Sovereignty: Does the Protection against Double Jeopardy Bar Successive Prosecutions in National and International Courts", 773.

${ }^{59}$ Colangelo. "Double Jeopardy and Multiple Sovereigns: A Jurisdictional Theory", 779. 
stated that the question of whether two entities are separate sovereigns "turns on whether the two entities draw their authority to punish the offender from distinct sources of power". ${ }^{60}$ Thus, for double jeopardy purposes the sovereignty of two prosecuting entities is determined by the ultimate source of the power under which the respective prosecutions were taken. ${ }^{61}$ If two entities have the same ultimate source of power, hence they both should be considered as one sovereign. ${ }^{62}$ With regard to the meaning of "last source of power", the Supreme Court explained in Heath v. Alabama that two entities are separate sovereigns when "each has the power, inherent in any sovereign, independently to determine what shall be an offense against its authority and to punish such offenses, and in doing so each is exercising its own sovereignty, not that of the other". 63

In applying the previous definition of sovereignty, the Supreme Court has ruled that, for double jeopardy purposes, a state and its municipalities are the same sovereign. ${ }^{64}$ Therefore, a state and its municipality are barred from prosecuting an individual for the same offence, not being applicable the double sovereignty doctrine. ${ }^{65}$ In holding this, the Supreme Court has emphasized that "political subdivisions of states - counties, cities or whatever - never were and never have been considered as sovereign entities. Rather, they have been traditionally regarded as subordinate government instrumentalities created by the state to assist in the carrying out of state governmental functions". ${ }^{66}$ Similarly, the federal government and its territories have been considered

${ }^{60}$ Heath v. Alabama, 88; William McAninch. "Unfolding the Law of Double Jeopardy", South Carolina Law Review, v. 44, n. 3 (1993): 425.

${ }^{61}$ United States v. Lara, 541 U.S. 193, 199 (2004); Heath v. Alabama, 90; United States v. Wheeler, 320.

62 Principato. "Defining the Sovereign in Dual Sovereignty: Does the Protection against Double Jeopardy Bar Successive Prosecutions in National and International Courts", 774.

${ }^{63}$ Heath v. Alabama, 89.

${ }^{64}$ Waller v. Florida, 394-395.

${ }^{65}$ Waller v. Florida, 394-395.

${ }^{66}$ Waller v. Florida, 392; Reynolds v. Sims, 377 U.S. 533, 575 (1964). 
the same sovereign for double jeopardy purposes. ${ }^{67}$ In deciding that the Philippines and the federal government were the same sovereign, the Court observed that "the government of a state does not derive its powers from the United States, while the government of the Philippines owes its existence wholly to the United States, and its judicial tribunals exert all their powers by the authority of the United States". ${ }^{6}$

These cases make clear that, if an entity derives its sovereignty from another entity, then according to the Supreme Court those entities should be considered the same sovereign for double jeopardy purposes. ${ }^{69}$

\section{Is there any safeguard against the dual sovereignty doctrine?}

Since its recognition, the dual sovereignty doctrine has been highly criticised. ${ }^{70}$ According to its critics, it offends individual's interest in finality and exposes defendants to capricious prosecutorial discretion. ${ }^{71}$ Another problem with the dual

67 United States v. Wheeler, 318; Puerto Rico v. Shell Co., 302 U.S. 253, 262-264 (1937); Grafton v. United States, 206 U.S. 333, 354 (1907); Principato. "Defining the Sovereign in Dual Sovereignty: Does the Protection against Double Jeopardy Bar Successive Prosecutions in National and International Courts", 775.

${ }^{68}$ Grafton v. United States, 354.

${ }^{69}$ Principato. "Defining the Sovereign in Dual Sovereignty: Does the Protection against Double Jeopardy Bar Successive Prosecutions in National and International Courts", 775 .

70 Michael Dawson directly affirms that the dual sovereignty doctrine is unconstitutional. Michael Dawson. "Popular Sovereignty, Double Jeopardy, and the Dual Sovereignty Doctrine”, Yale Law Journal, v. 102, n. 1 (1992): 299-302.

${ }^{71}$ Cranman. "The Dual Sovereignty Exception to Double Jeopardy: A Champion of Justice or a Violation of a Fundamental Right", 1667. Suggesting a serious reexamination of the dual sovereignty doctrine after Benton v. Maryland, Richard Boyle. "Double Jeopardy and Dual Sovereignty: The Impact of Benton v. Maryland on 
sovereignty doctrine would be that it is almost limitless, existing an extreme potential for abuse. ${ }^{72}$

Although the double jeopardy clause does not bar a federal prosecution following a state prosecution for the same conduct, in response to the Bartkus decision the Department of Justice instituted the Petite Policy, ${ }^{73}$ which places limits on the federal government's prosecutorial discretion, thereby assuaging fears of arbitrary successive prosecutions. ${ }^{74}$ The Petite Policy establishes guidelines for the exercise of discretion by the Department of Justice in determining whether to bring a federal prosecution based on substantially the same acts involved in a prior state or federal proceeding. ${ }^{75}$ The Petite Policy "precludes the initiation or continuation of a federal prosecution, following a prior state or federal prosecution based on substantially the same act(s) or transaction(s) unless three substantive prerequisites are satisfied": first, the matter must involve a substantial federal interest; second, the prior prosecution must have left that interest demonstrably unvindicated; and third, the defendant's conduct must constitutes a federal offence and the admissible evidence should be probably sufficient to obtain and sustain a conviction. In addition, the prosecution must be approved by the appropriate Assistant Attorney

Successive Prosecution for the Same Offense by State and Federal Governments", Indiana Law Journal, v. 46, n. 3 (1971): 422-427. Similarly, Mullen. “Gamble v. United States: A Commentary", 218; Stoner. "Double Jeopardy and Dual Sovereignty: A Critical Analysis", 952-954.

72 Cranman. "The Dual Sovereignty Exception to Double Jeopardy: A Champion of Justice or a Violation of a Fundamental Right”, 1669.

${ }^{73}$ The Petite Policy derives its name from Petite v. United States, 361 U.S. 529 (1960). Rudstein, Double Jeopardy..., 87; Dawson. "Popular Sovereignty, Double Jeopardy, and the Dual Sovereignty Doctrine", 293.

${ }^{74}$ Owsley. "Accepting the Dual Sovereignty Exception to Double Jeopardy: A Hard Case Study", 793; Ellen Podgor. "Department of Justice Guidelines: Balancing Discretionary Justice", Cornell Journal of Law and Public Policy, v. 13, n. 2 (2004): 177-181.

75 Justice Manual, Title 9: Criminal, Section 9-2.031 - Dual and Successive Prosecution Policy. 
General. ${ }^{76}$ In determining whether a second prosecution may be authorized, it has been noted that the second criterion is critical. ${ }^{77}$ Satisfaction of these requisites does not mean however that a proposed prosecution must be approved or brought, since traditional elements of federal prosecutorial discretion continue to apply. ${ }^{78}$

Even though the government has discretion to dismiss cases when its Petite policy is violated, ${ }^{79}$ defendants are not afforded this same opportunity. Because courts have found that the Petite Policy is a mere government policy, rather than a matter of constitutional law, ${ }^{80}$ defendants "may not seek dismissal of a federal prosecution on the ground that the government brought the prosecution in violation of the policy". ${ }^{81}$

As can be imagine, unfortunately there are no records concerning the discussion and the decision of the Department of Justice on the application of the Petit Policy to the specific case of Gamble. However, at least at first sight it would seem debatable the satisfaction of the first and the second requirements of the Policy. Indeed, the defendant had already been convicted to one year in prison for a crime that was neither a violent nor a serious offence. Did the matter involve a substantial federal interest? Had the state prosecution left a federal interest without vindicating? The case of Gamble could be a good example to illustrate the shortcomings of the Petit Policy.

In addition to the Petite Policy, David Owsley has stated that potential abuses of the dual sovereignty doctrine are checked by the political accountability of the executive

${ }^{76}$ Justice Manual, Title 9: Criminal, Section 9-2.031 - Dual and Successive Prosecution Policy; Podgor. "Department of Justice Guidelines: Balancing Discretionary Justice", 178; John Cooney. "Multi-Jurisdictional and Successive Prosecution of Environmental Crimes: The Case for a Consistent Approach", Journal of Criminal Law and Criminology, v. 96, n. 2 (2006): 448.

${ }^{77}$ Cooney. "Multi-Jurisdictional and Successive Prosecution of Environmental Crimes: The Case for a Consistent Approach", 448.

${ }^{78}$ Justice Manual, Title 9: Criminal, Section 9-2.031 - Dual and Successive Prosecution Policy.

${ }^{79}$ For instance, Thompson v. United States, 444 U.S. 248 (1980); Marakar v. United States, 370 U. S. 723 (1962); Petite v. United States, 361 U. S. 529 (1960).

${ }^{80}$ Podgor. "Department of Justice Guidelines: Balancing Discretionary Justice", 179180.

${ }^{81}$ Rudstein, Double Jeopardy..., 87. 
branch; state legislation; federal sentencing guidelines that can prevent duplicative punishment or mitigate the unfairness of a successive prosecution; and continuing vigilance of state and national electorates who can consent at any time through legislation, generally or particularly tailored, to the adjudications of other jurisdictions. $^{82}$

Although it can be certainly argued that these safeguards are not very robust, especially the political accountability of the executive branch and the continuing vigilance of state and national electorates, the merit of Owsley is having put the focus on other kind of safeguards, different to the double jeopardy clause. Indeed, as Adam Adler has pointed out, the problem with most of the criticisms against the dual sovereignty doctrine is that they focus too much on the double jeopardy clause and the dual sovereignty doctrine itself, excluding other legal or constitutional provisions. ${ }^{83}$

It is important to highlight that the same Supreme Court has recognised that some of the ills at which some interpretations on double jeopardy have been directed are addressed by other constitutional provisions. ${ }^{84}$

Some additional protections against potential abuses of the dual sovereignty doctrine that could be developed are the due process clause, ${ }^{85}$ the prohibition of cruel and unusual punishments and the excessive fines clause, both established in the Eighth Amendment, ${ }^{86}$ and the collateral estoppel. ${ }^{87}$ The study of all these guarantees and protections is indubitably beyond the possibilities of this comment. Nevertheless,

82 Owsley. "Accepting the Dual Sovereignty Exception to Double Jeopardy: A Hard Case Study", 795-796.

${ }^{83}$ For example, King. "The Problem of Double Jeopardy in Successive Federal-State Prosecutions: A Fifth Amendment Solution", 478, has suggested a "fifth amendment standard that solves the "over breadth" problem inherent in the Bartkus-Abbate rule". ${ }^{84}$ Hudson v. United States, 522 U.S. 93, 102-103 (1997).

85 Adler. "Dual Sovereignty, Due Process, and Duplicative Punishment: A New Solution to an Old Problem", 451.

86 Nancy King. "Portioning Punishment: Constitutional Limits on Successive and Excessive Penalties", University of Pennsylvania Law Review, v. 144, n. 1 (1995): 150.

${ }^{87}$ Nina Shreve. "Expanded Application of Collateral Estoppel Defense in Criminal Prosecutions (United States ex rel. Rogers v. LaVallee)", John's Law Review, v. 50, n. 2 (2012): 339-347. 
considering that it is quite probable that the Supreme Court will not overrule the dual sovereignty doctrine, at least not in the near future, their further study is highly recommended.

Contribución: $100 \%$ del autor.

\section{Bibliography}

Adler, Adam. "Dual Sovereignty, Due Process, and Duplicative Punishment: A New Solution to an Old Problem", Yale Law Journal, v. 124, n. 2 (2014): 448-483.

Allen, Ronald and Ratnaswamy, John. "Heath v. Alabama: A Case Study of Doctrine and Rationality in the Supreme Court", Journal of Criminal Law and Criminology, v. 76, n. 4 (1985): 801-831.

Boyle, Richard. "Double Jeopardy and Dual Sovereignty: The Impact of Benton v. Maryland on Successive Prosecution for the Same Offense by State and Federal Governments", Indiana Law Journal, v. 46, n. 3 (1971): pp. 413-427.

Brickman, Jay. "The Dual Sovereignty Doctrine and Successive State Prosecutions: Health v. Alabama”, Chicago-Kent Law Review, v. 63, n. 1 (1987): 175-188.

Colangelo, Anthony. "Double Jeopardy and Multiple Sovereigns: A Jurisdictional Theory", Washington University Law Review, v. 86, n. 4 (2009): 769-857.

Cooney, John. "Multi-Jurisdictional and Successive Prosecution of Environmental Crimes: The Case for a Consistent Approach", Journal of Criminal Law and Criminology, v. 96, n. 2 (2006): 435-464.

Cranman, Erin. “The Dual Sovereignty Exception to Double Jeopardy: A Champion of Justice or a Violation of a Fundamental Right”, Emory International Law Review, v. 14, n. 3 (2000): 1641-1679.

Dawson, Michael. "Popular Sovereignty, Double Jeopardy, and the Dual Sovereignty Doctrine", Yale Law Journal, v. 102, n. 1 (1992): 281-303.

Fisher, Walter. "Double Jeopardy, Two Sovereignties and the Intruding Constitution", The University of Chicago Law Review, v. 28, n. 4 (1961): 591-613.

King, James. "The Problem of Double Jeopardy in Successive Federal-State Prosecutions: A Fifth Amendment Solution”, Stanford Law Review, v. 31 , n. 3 (1979): 477-504. 
King, Nancy. "Portioning Punishment: Constitutional Limits on Successive and Excessive Penalties", University of Pennsylvania Law Review, v. 144, n. 1 (1995): 101196.

Koklys, Andrea. "Second Chance for Justice: Reevaluation of the United States Double Jeopardy Standard”, John Marshall Law Review, v. 40, n. 1 (2006): 371-394.

McAninch, William. "Unfolding the Law of Double Jeopardy", South Carolina Law Review, v. 44, n. 3 (1993): 411-505.

Mullen, Kayla. "Gamble v. United States: A Commentary". Duke Journal of Constitutional Law \& Public Policy, v. 14, n. 1 (2019): pp. 207-219.

Owsley, David. "Accepting the Dual Sovereignty Exception to Double Jeopardy: A Hard Case Study", Washington University Law Review, v. 81, n. 3 (2003): 765-800.

Patraus, Darius. "The non bis in idem principle in the case law of the Court of Justice of the European Union -consistency or inconsistency?", AGORA International Journal of Juridical Sciences, n. 1 (2018): 25-34.

Podgor, Ellen. "Department of Justice Guidelines: Balancing Discretionary Justice", Cornell Journal of Law and Public Policy, v. 13, n. 2 (2004): 167-202.

Principato, Daniel. "Defining the Sovereign in Dual Sovereignty: Does the Protection against Double Jeopardy Bar Successive Prosecutions in National and International Courts", Cornell International Law Journal, v. 47, n. 3 (2014): 767-785.

Reed, Akhil and Marcus, Jonathan. "Double Jeopardy Law After Rodney King", Columbia Law Review, v. 95, n. 1 (1995): 1-59.

Rudstein, David. Double Jeopardy. A Reference Guide to the United States Constitution. Westport: Praeger, 2004.

Rudstein, David. “A Brief History of the Fifth Amendment Guarantee Against Double Jeopardy”, William \& Mary Bill of Rights Journal, v. 14, n. 1 (2005): 193-242.

Sigler, Jay. "A History of Double Jeopardy", American Journal of Legal History, v. 7, n. 4 (1963): 283-309.

Sigler, Jay. "Federal Double Jeopardy Policy", Vanderbilt Law Review, v. 19, n 2 (1966): 305-405.

Shreve, Nina. "Expanded Application of Collateral Estoppel Defense in Criminal Prosecutions (United States ex rel. Rogers v. La Vallee)", John's Law Review, v. 50, n. 2 (2012): 339-347.

Stoner, Ray. "Double Jeopardy and Dual Sovereignty: A Critical Analysis", William \& Mary Law Review, v. 11, n. 4 (1970): 946-959. 
Summers, Brian. "Double Jeopardy: Rethinking the Parameters of the Multiplicity Prohibition", Ohio State Law Journal, v. 56, n. 5 (1995): 1595-1617.

Thomas III, George. Double Jeopardy. The History, the Law. New York: New York University Press, 1998. 